Available online on 15.02.2020 at http://jddtonline.info
Open Access to Pharmaceutical and Medical Research
unrestricted non-commercial use, provided the original work is properly cited

Open $\odot$ Access

Research Article

\title{
Bradford assay as a high-throughput bioanalytical screening method for conforming pathophysiological state of the animal
}

\author{
Abhishesh Kumar Mehata*1, Deepa Dahari ${ }^{1}$ \\ ${ }^{1}$ Department of Pharmaceutical Engineering and Technology, Indian Institute of Technology (BHU), Varanasi-221005, India
}

\begin{abstract}
Proteins are the essential components of the tissues that play a key role in the body. Its expression in the cell or tissue under a specified set of conditions and at a particular time regulates the different body conditions either as a normal body function or as a disease state. Protein is an important building block of muscles, skin, cartilage, bones and blood. Bradford assay is a reliable advanced and cost-effective protein estimation test for determining the exact concentration of protein in different tissues of the animal. In this study, we have taken a rat suffering from protein deficiency disorder and total protein concentration in the heart, brain, liver, blood and kidney was determined. It was found that the total protein concentration in different tissues of rat i.e., heart, brain, liver, plasma and kidney was found to be $8.39 \pm 0.75,10.46 \pm 0.76,6.74 \pm$ $0.39,8.12 \pm 0.32 \mathrm{mg} / \mathrm{g}$ of tissue and $61.27 \pm 0.95 \mathrm{mg} / \mathrm{mL}$ of plasma respectively (mean \pm SEM). As compared to earlier published reports the total protein concentration in different tissues like hear, brain, liver and kidney found much lower to standard value as reported by Beyer, the reason behind obtaining this kind of results may be due to the presence of insufficient amount of the protein content in different tissue of animal as suffering from protein degeneration disorder. The rat was unable to digest and store the protein or catabolism was much faster than anabolism.
\end{abstract}

Keywords: Anabolism, Bradford assay, Catabolism, Protein estimation.

Article Info: Received 28 Nov 2019; $\quad$ Review Completed 22 Jan 2020; $\quad$ Accepted 30 Jan 2020; Available online 15 Feb 2020

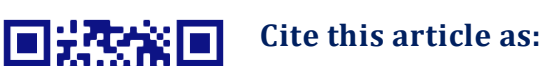

Mehata AK, Dahari D, Bradford assay as a high-throughput bioanalytical screening method for conforming pathophysiological state of the animal, Journal of Drug Delivery and Therapeutics. 2020; 10(1-s):105-110 http://dx.doi.org/10.22270/jddt.v10i1-s.3921

*Address for Correspondence:

Abhishesh Kumar Mehata, Department of Pharmaceutical Engineering and Technology, Indian Institute of Technology (BHU), Varanasi 221005, India

\section{INTRODUCTION}

Proteins are large, complex molecules that play many critical roles in the body. They do most of the work in cells and are required for the structure, function, and regulation of the body's tissues and organs. The cellular structure has many components that help to maintain different body function like DNA carries genetic information, RNA helps to synthesize various proteins and proteins make different enzymes, hormones and other body chemicals [1]. Protein is an important building block of muscles, skin, cartilage, bones and blood. Every protein has a specific role in the body. Its expression in the cell or tissue under a specified set of conditions and at a particular time regulate the different body conditions either as a normal body function or as a disease state [2]. Apart from that, proteins also induce the enzyme activity \& transport of nutrients or biochemical compounds through the different biological membranes. It has an extensive role in the maintenance and growth of the human body and also provides energy as a nutrient [3]. Total protein content in tissues plays an important role to maintain the state of health in a living organism [4].

With the help of rapid advancements in molecular biology and genetic engineering, a rising number of biotherapeutics are being developed and marketed. The quality and safety requirements for this class of active ingredients has steadily increased over the decades since Eli Lilly put forth the first insulin manufactured using genetically modified organisms in 1982. This has led to dynamic developments in protein analysis and proteomics intended to meet a growing demand for new technologies and sophisticated analytical techniques to characterize therapeutic proteins [5]. To understand the correlation between protein concentrations with physiological activities, protein content profiling is needed. Protein content profiling includes identifying the protein content in a particular tissue under a specified set of conditions and at a particular time. Usually determination of protein content in tissue done as compared to a reference solution containing bovine serum albumin [2]. 
Although, estimation of the protein content of a variety of biological samples consisting of complex protein mixtures and a multitude of other biological macromolecules, has remains as challenging task for biochemists. Determination of absolute protein content can be best performed by measuring the amino acid content of the proteins in the studied samples. This procedure, however, requires specialized equipment, which is not readily available. Thus a number of other methods, which yield relative estimates of protein content, are being employed as an acceptable compromise depending on the researcher's needs [6].

Various estimation assay and methods are utilized to determine protein concentration in different tissues (Table 1 and 2). The most common used methods for protein estimation are the Biuret method, Bradford assay and Lowry method. Biuret method indicated the lowest content of proteins or albumin which was probably due to the low sensitivity of this method. The Biuret assay is not much good for protein concentrations below $5 \mathrm{mg} / \mathrm{ml}$. By using the Folin-Ciocalteu reagent to detect reduced copper makes the Lowry assay nearly 100 times more sensitive than Biuret reaction alone [7]. A rapid and accurate method for the estimation of protein concentration is essential in many fields of protein study. An assay originally described by Bradford has become the preferred method for quantifying protein in many laboratories. This technique is simpler, faster, and more sensitive than the Lowry method. Moreover, when compared with the Lowry method, it is subject to less interference by common reagents and nonprotein components of biological samples [8].
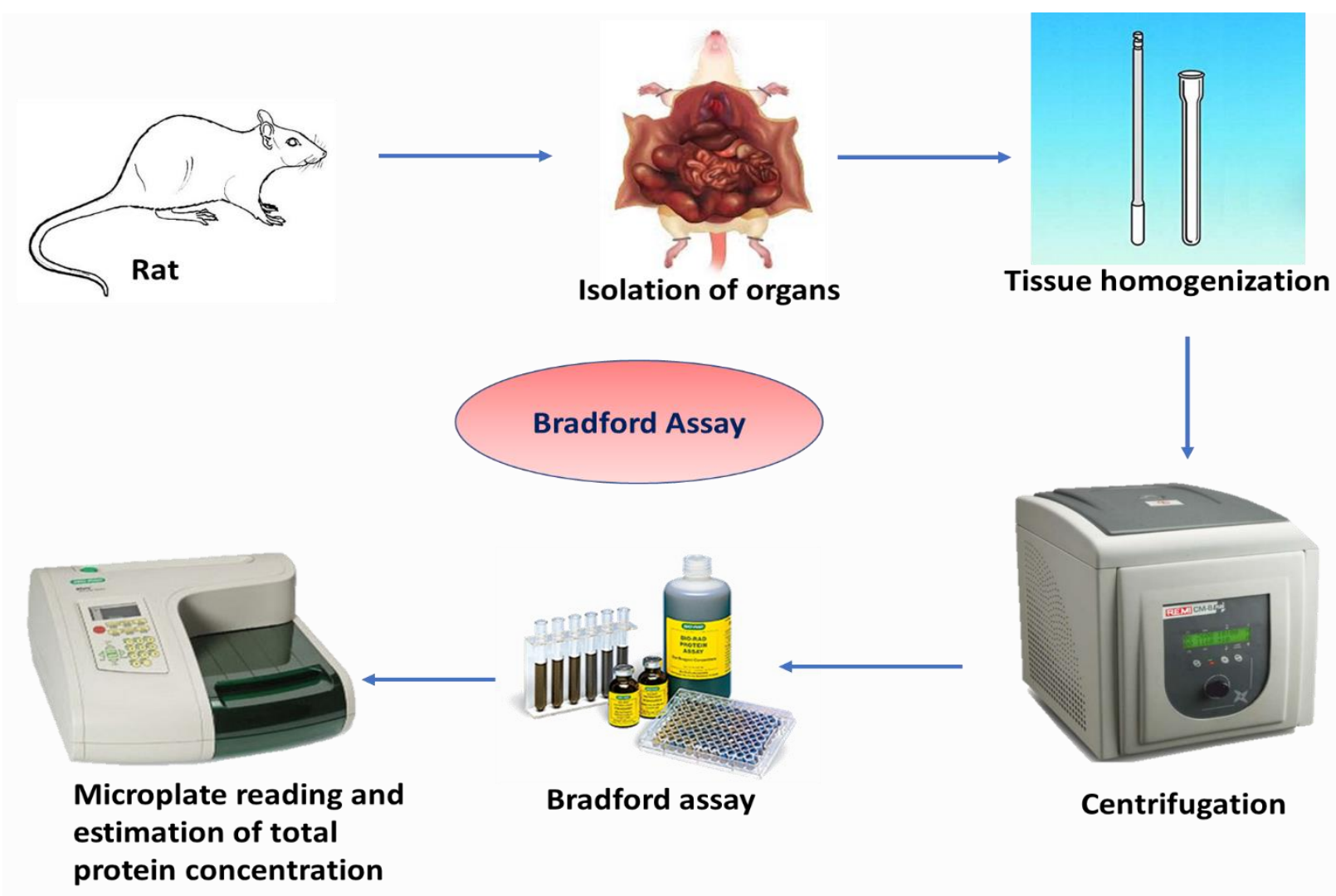

Fig.1: Schematic representation of sequential estimation of total protein content by Bradford assay

One of the main challenges in proteomics nowadays is absolute protein quantification, a must in order to get a deeper understanding of protein functions and their interaction networks. In particular, that type of quantitative knowledge turns out to be critical now to assess the potential of biomarkers in clinical applications [9]. The Coomassie brilliant blue protein assay, known as the Bradford assay, is widely used because of its ease of performance, rapidity, relative sensitivity, and specificity for proteins. The reagent used in this assay bind to the protein and gives a blue color that absorbs at $595 \mathrm{~nm}$ in UV spectrophotometer [10].
The aim of this study was to estimate total protein content in different tissues of rat and correlating with earlier reported values in literature and thus conforming to the physiological state of the animal under investigation. Bradford test was selected for protein estimation analysis because it is less time consuming, sufficiently selective and sensitive, reagents used were available easily and comparatively fewer steps involved to perform a test. 
Table 1: Comparative protein estimation test part 1

\begin{tabular}{|c|c|c|c|c|c|c|}
\hline $\begin{array}{l}\text { Protein } \\
\text { estimation } \\
\text { tests }\end{array}$ & Principle & Sensitivity & Selectivity & Time & Easiness & Cost \\
\hline Biuret test & $\begin{array}{l}\text { A violet-purplish } \\
\text { color is produced } \\
\text { when cupric ions } \\
(\mathrm{Cu} 2+) \text { interact } \\
\text { with peptide } \\
\text { bonds under } \\
\text { alkaline } \\
\text { conditions. }\end{array}$ & $\begin{array}{l}\mathbf{1 m g} / \mathbf{m l} \\
\text { less sensitive to } \\
\text { protein type due to } \\
\text { availability of peptide } \\
\text { bond to all protein } \\
\text { [11]. } \\
* *\end{array}$ & $\begin{array}{l}\text { Peptide bonds } \\
\text { detection at } \lambda \\
540 \mathrm{~nm} \text {, }\end{array}$ & $\begin{array}{l}20- \\
30 \min \end{array}$ & $\begin{array}{l}\text { Easy } \\
\\
\\
\\
* * * *\end{array}$ & $\begin{array}{l}\text { Rs 16,990 } \\
\text { INR for } \\
500 \mathrm{ml} \\
\\
\text { **** }\end{array}$ \\
\hline $\begin{array}{l}\text { Folin-Lowry } \\
\text { test }\end{array}$ & $\begin{array}{l}\text { It complexes } \\
\text { copper with the } \\
\text { nitrogen gives } \\
\text { blue-green color } \\
\text { which absorbs at } \\
650-750 \mathrm{~nm} \text { [12]. }\end{array}$ & $\begin{array}{l}\mathbf{1 \mu g} / \mathbf{m l} \\
\text { Endpoint assay with a } \\
\text { stable result, i.e } \\
\text { comparing it with a } \\
\text { previous standard } \\
\text { curve. } \\
* * *\end{array}$ & $\begin{array}{l}\text { Aromatic } \\
\text { amino acids, as } \\
\text { tryptophan, } \\
\text { tyrosine, } \\
\text { cysteine } \\
* * *\end{array}$ & $2 \mathrm{hrs}$ & $\begin{array}{l}\text { Incompatibility } \\
\text { with EDTA, Tris, } \\
\text { reducing agents } \\
\text { [13]. } \\
\text { ** }\end{array}$ & $\begin{array}{l}500 \mathrm{ml} \\
\text { (Folin- } \\
\text { Ciocalteu } \\
\text { phenol) } \\
\text { cost is } \\
12,358 \\
\text { INR } \\
* *\end{array}$ \\
\hline Bradford test & $\begin{array}{l}\text { Negatively- } \\
\text { charged } \\
\text { Coomassie } \\
\text { brilliant blue dye } \\
\text { binds to positively- } \\
\text { charged proteins. }\end{array}$ & $\begin{array}{l}\mu \mathrm{g} / \mathrm{ml} \\
{[14]} \\
* * * *\end{array}$ & $\begin{array}{l}\text { Aromatic } \\
\text { amino acids } \\
\text { arginine, } \\
\text { tryptophan } \\
\text { and proline at } \\
\lambda 465-595 \mathrm{~nm} \\
* * * *\end{array}$ & $15 \mathrm{~min}$ & $\begin{array}{l}\text { The Bradford } \\
\text { reaction is fast, } \\
\text { easy, and stable } \\
\text { for up to an hour } \\
{[15] \text {. }} \\
* * *\end{array}$ & $\begin{array}{l}500 \mathrm{ml} \\
\text { cost is } \\
6,868 \mathrm{INR}\end{array}$ \\
\hline $\begin{array}{l}\text { Bicinchoninic } \\
\text { acid assay }\end{array}$ & $\begin{array}{l}\text { Colorimetric, } \\
1^{\text {st }} \text { complex the } \\
\text { protein with } \\
\text { copper ions. } \\
\text { secondly, this } \\
\text { chelates BCA to } \\
\text { give an intense } \\
\text { purple color [16]. }\end{array}$ & 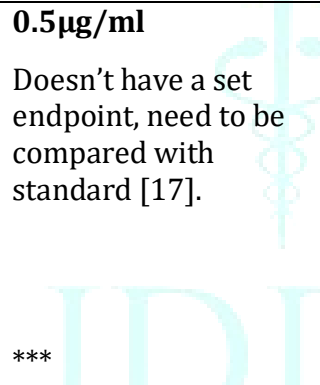 & $\begin{array}{l}\text { Aromatic } \\
\text { amino acids } \boldsymbol{\lambda} \\
\mathbf{5 6 2} \mathbf{~} \mathbf{m m} . \\
\text { interference } \\
\text { with surfactant } \\
\text { if present } \\
\text { more than } 5 \% \\
\text { ** }\end{array}$ & $35 \mathrm{~min}$ & Not easy & $\begin{array}{l}\text { 1 L BCA is } \\
33,211 \\
\text { INR } \\
\text { (Very } \\
\text { Costly) }\end{array}$ \\
\hline
\end{tabular}

*- Very less useful, ${ }^{* *}$ - Less useful, ${ }^{* * *}$ - Useful, ${ }^{* * * *}$ Highly useful 
Table 2: Comparative protein estimation test part 2

\begin{tabular}{|c|c|c|c|c|c|c|}
\hline $\begin{array}{l}\text { Protein } \\
\text { estimation } \\
\text { tests }\end{array}$ & Principle & Sensitivity & Selectivity & Time & Easiness & Cost \\
\hline Kjeldahl & $\begin{array}{l}\text { Nitrogen sin a protein } \\
\text { sample after it's been } \\
\text { converted to ammonia }\end{array}$ & $\begin{array}{l}\text { 1g sample } \\
\text { Tedious and } \\
\text { time- } \\
\text { consuming } \\
* *\end{array}$ & $\begin{array}{l}\text { A series of terrifying } \\
\text { steps involving } \\
\text { heated sulfuric acid, } \\
\text { steam distillation, } \\
\text { and back-titration } \\
\text { with sodium } \\
\text { hydroxide. } \\
* *\end{array}$ & $\begin{array}{l}60 \\
\min \end{array}$ & Difficult & $\begin{array}{l}\text { Costly and } \\
\text { tedious due to } \\
\text { multi-step, } \\
\text { highly } \\
\text { impractical [19]. } \\
*\end{array}$ \\
\hline $\begin{array}{l}\text { Fluorometric } \\
\text { method }\end{array}$ & $\begin{array}{l}\text { Attaching fluorophore } \\
\text { to protein and recording } \\
\text { fluorescence [20] }\end{array}$ & $\begin{array}{l}\text { Less } \\
*\end{array}$ & $\begin{array}{l}\text { Primary amines in } \\
\text { proteins } \\
* *\end{array}$ & $\begin{array}{l}90 \\
\min \end{array}$ & $* *$ & $\begin{array}{l}\text { Average } \\
* * *\end{array}$ \\
\hline $\begin{array}{l}\text { Turbimetric } \\
\text { method }\end{array}$ & $\begin{array}{l}\text { Protein molecules } \\
\text { which are normally } \\
\text { soluble in the solution } \\
\text { can be made to } \\
\text { precipitate by the } \\
\text { addition of certain } \\
\text { chemicals, e.g., } \\
\text { trichloroacetic acid. }\end{array}$ & $\begin{array}{l}\text { Less } \\
\text { sensitive } \\
\text { compared to } \\
\text { Bradford } \\
\\
* *\end{array}$ & $\begin{array}{l}\text { Protein precipitation } \\
\text { causes the solution to } \\
\text { become turbid. Thus } \\
\text { the concentration of } \\
\text { protein can be } \\
\text { determined by } \\
\text { measuring the degree } \\
\text { of turbidity [21]. } \\
* *\end{array}$ & $\begin{array}{l}10 \\
\min \end{array}$ & $* * *$ & $\begin{array}{l}\text { Rs } 12,869 \text { for } \\
500 \mathrm{gm}\end{array}$ \\
\hline
\end{tabular}

*- Very less useful, ** - Less useful, *** - Useful, **** Highly useful

\section{MATERIALS AND METHODS}

\section{Materials}

Bradford reagent, distill water, bovine serum albumin (BSA), sodium chloride, potassium chloride, disodium phosphate, potassium dihydrogen phosphate was purchased from Sigma Aldrich Bangalore India. Microplate, absorbance reader (BIO-RAD), Volumetric flask (500 L), Pipettes (200 $\mu \mathrm{L}, 10 \mu \mathrm{L}, 1 \mathrm{~mL})$, Weighing balance, Centrifuge, Glass tube homogenizer, Beaker, Centrifuge tubes. Glassware was of borosilicate and other chemicals were of analytical grades.

\section{Methods}

\section{Phosphate buffer saline (pH 7.4)}

Phosphate buffer saline (PBS) was prepared by using $8 \mathrm{~g}$ of sodium chloride $(\mathrm{NaCl}), 0.2 \mathrm{~g}$ of potassium chloride $(\mathrm{KCl})$, $1.44 \mathrm{~g}$ of disodium phosphate $\left(\mathrm{Na}_{2} \mathrm{HPO}_{4}\right)$, and $0.24 \mathrm{~g}$ of potassium dihydrogen phosphate $\left(\mathrm{KH}_{2} \mathrm{PO}_{4}\right)$ and dissolved in some amount of distilled water. Further, more amount of distilled water was added to make up to the total volume of $1000 \mathrm{ml}$. The $\mathrm{pH}$ of the obtained buffer was adjusted to 7.4 with dil. Hydrochloric acid [22].

Preparation of bovine serum albumin (BSA) stock solution

Accurately weighed $10 \mathrm{mg}$ of BSA was dissolved in $10 \mathrm{~mL}$ of phosphate buffer saline ( $\mathrm{pH} 7.4)$ to produce a solution of 1 $\mathrm{mg} / \mathrm{mL}$ concentration.

\section{Preparation of $10 \%(w / v)$ tissue homogenate}

The rat was sacrificed in $\mathrm{CO}_{2}$ chamber and different organs were isolated and processed in the presence of ice packs in order to prevent degradation of proteins in the tissues. The tissue of the brain, liver, heart and blood plasma of the three rats were extracted as stated. The weighed amount of tissues was homogenized in PBS in a proportion of 1:10 (w/v) ratio by using a glass tissue homogenizer on ice bath. Then, obtained homogenates were collected in tubes and centrifuged (REMI cooling centrifuge) at 12000 RPM for 45 minutes at $4{ }^{\circ} \mathrm{C}$ [23]

\section{Bradford Assay}

The standard calibration curve of BSA was prepared by using, 6.25, 12.5, 25, 50, 100 and $200 \mu \mathrm{L}$ of $1 \mathrm{mg} / \mathrm{mL}$ BSA stock solution in an Eppendorf tube with a further addition of PBS up to the volume $1000 \mu \mathrm{L}$. The addition was done by using a micropipette. Each sample of the tissue homogenate (100 times diluted) and a standard solution of the calibration curve were taken in the microwell plate in a triplicate manner $(10 \mu \mathrm{L})$. For the detection of protein content, $250 \mu \mathrm{L}$ of Bradford's reagent was added to each microwell. The microwell plate was incubated at room temperature for 10 minutes in a dark place. Finally, the produced color was analyzed by using a microplate reader at $595 \mathrm{~nm}$ wavelength [24].

\section{Preparation of calibration curve}

The obtained absorbance of the different standard concentrations of BSA solution was calculated by subtracting 


\section{Mehata et al}

the mean absorbance of blank (PBS) from each absorbance value of a standard solution. Then the mean of triplicate value for each concentration was calculated. The standard curve was plotted between the BSA concentration on X-axis and the mean absorbance on Y-axis (Fig.2).

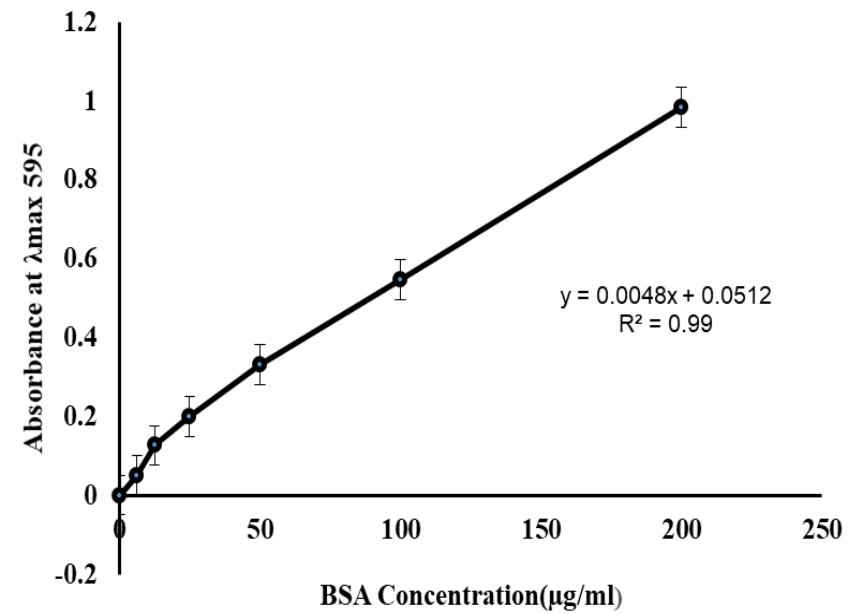

Fig. 2: Calibration curve of BSA in PBS at $595 \mathrm{~nm}$. The obtained linear equation, $\mathrm{y}=0.0048 \mathrm{x}+0.0512$ with $\mathrm{R}^{2}=$ 0.99 , where $y$ is absorbance and $x$ represent respective BSA concentration.

\section{Statistical analysis}

Protein concentration in the different samples was determined by using the GraphPad Prism software. Values are given as mean \pm S.D. The significance of differences was analyzed by one-way analysis of variance and subsequent Tukey's multiple comparisons test. Differences among means were considered significant when $P<0.05$.

\section{RESULTS AND DISCUSSIONS}

In this study, it was found that the total protein concentration in different tissues of rat i.e., heart, brain, liver, plasma, and kidney was found to be $8.39 \pm 0.75,10.46$ $\pm 0.76,6.74 \pm 0.39,8.12 \pm 0.32 \mathrm{mg} / \mathrm{g}$ of tissue and $61.27 \pm$ $0.95 \mathrm{mg} / \mathrm{mL}$ of plasma respectively (mean \pm SEM). As compared to earlier published reports as mention as in table 3 , the total protein concentration in different tissues like hear, brain, liver and kidney found to not up to standard value as reported by Beyer 1983, the reason behind obtaining this kind of results may be due to the presence of insufficient amount of the protein content in different tissue of animal as suffering from protein degeneration disorder. The rat was unable to digest and store the protein or catabolism was much faster than anabolism

Table 3: Comparison of the experiment results with respect to the earlier data

\begin{tabular}{ccc}
\hline Tissue & \multicolumn{2}{c}{$\begin{array}{c}\text { Total protein concentration } \\
\text { (mean } \pm \text { SEM) }\end{array}$} \\
\cline { 2 - 3 } & Present study & Earlier data \\
\hline Heart $(\mathrm{mg} / \mathrm{g})$ & $8.39 \pm 0.75$ & $83.64 \pm 0.52[25]$ \\
Brain $(\mathrm{mg} / \mathrm{g})$ & $10.46 \pm 0.76$ & $44.45 \pm 1.04[25]$ \\
Liver $(\mathrm{mg} / \mathrm{g})$ & $6.74 \pm 0.39$ & $102.92 \pm 1.14[25]$ \\
Blood $(\mathrm{mg} / \mathrm{mL})$ & $61.27 \pm 0.95$ & $60.53 \pm 2.65[26]$ \\
Kidney $(\mathrm{mg} / \mathrm{g})$ & $8.12 \pm 0.32$ & $51.38 \pm 0.48[25]$ \\
\hline
\end{tabular}

The protein content of Blood or plasma was found to be satisfactory and it is similar to the reported values in literature. The reason behind obtaining satisfactory results
Journal of Drug Delivery \& Therapeutics. 2020; 10(1-s):105-110

in case of blood samples was due to the fact that animal can absorb the proteins but from the blood, it was unable to utilize for anabolic activities and also blood samples processing step does not involve any homogenization process so chances of degradation of protein during the process are very rare.

There may be several factors that may have affected the outcomes of the experiment i.e., large result deviations. Small volume measurement may be one of the limiting factors in the analysis. Temperature is another important factor because during the experiment it has been observed that temperature could affect Bradford reagent stability [27]. Thoroughly mixing of the protein sample and Bradford reagent may also affect the binding of the dye to the protein and thus the absorbance. When the total protein concentration was statistically compared within the different tissues, it was found that there is a statistically significant difference between the total protein concentration in the liver when compared to plasma and in the heart and brain when compared to the liver.

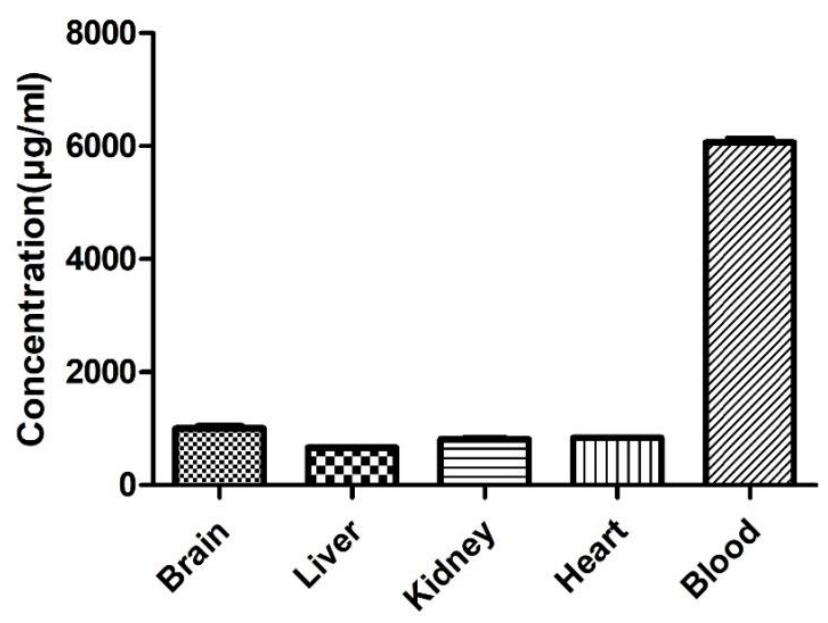

Fig. 3: Histogram of total protein concentration in different tissues of rat. Mean \pm S.D.; $P<0.05$, versus plasma, $\mathrm{P}<0.05$, versus liver.

Generally, the organs like heart, brain, and liver are highly perfused with the blood, and the total protein concentration in the liver is found to be highest as compared to other tissues. It may be due to the reason that the liver consists of a large number of metabolizing enzymes as well as protein synthesis takes place in the liver.

It was demonstrated that normalization using total protein analysis (TPA) with stains such as Coomassie and Instant blue provides a more robust baseline for performing quantitative Western blotting (QWB) experiments. The Western blotting is widely used for determining the presence or absence of a protein within a cellular homogenate. Total protein analysis is an accurate measure of protein load. The use of total protein analysis provides a measure of protein load that circumvents many of the problems associated with the use of single loading control proteins. [28]. Total protein analysis is an alternative simple technique in quantitative Western blotting to accurately determine if equivalent protein loading has been achieved within a gel [29]. While proteomics remains the tool of choice for discovery research, new innovations in proteomic technology now offer the potential for proteomic profiling to become standard practice in the clinical laboratory. Indeed, protein profiles can serve as powerful diagnostic markers and can predict treatment outcome in many diseases, in particular, cancer [30]. 


\section{CONCLUSION}

In this experiment, accurate and comparable measurement of the total protein concentration in different tissues of rats (heart, brain, liver, and plasma) was determined by using the Bradford assay. The assay was carried out in a 96-well plate and allowing less utilization of the ingredients. That gives the cost-effectiveness of the method with high-throughput screening. The results were statistically compared and it was found that total protein concentration in blood was significantly different as compared to other organs and the same was true for heart and brain when compared to blood plasma. The obtained results suggest that the rat was suffering from tissue protein degeneration disease. The estimation of total protein is helpful in experimental research as it provides a measure of protein load that avoids many problems associated with the use of single loading control proteins. Therefore, it is can be expanded to realize accurate and comparable biological measurements according to other reference methods.

\section{CONFLICT OF INTEREST}

The authors have no conflict of interest to report.

\section{REFERENCES}

1. Graslund S, Nordlund P, Weigelt J, Hallberg BM, Bray J, Gileadi O, Knapp S, Oppermann U, Arrowsmith C, Hui R, Ming J. Protein production and purification. Nature methods, 2008; (2):135.

2. Bradley BP, Kalampanayil B, O'Neill MC. Protein expression profiling. In Two-Dimensional Electrophoresis Protocol. Springer Humana Press,.2009; 455-468.

3. Maehre HK, Dalheim L, Edvinsen GK, Elvevoll EO, Jensen IJ. Protein determination-method matters. Foods, 2018; 7(1):5.

4. Zheng K, Wu L, He Z, Yang B, Yang Y. Measurement of the total protein in serum by biuret method with uncertainty evaluation. Measurement, 2017; 1(112):16-21.

5. Mircean C, Shmulevich I, Cogdell D, Choi W, Jia Y, Tabus I, Hamilton SR, Zhang W. Robust estimation of protein expression ratios with lysate microarray technology. Bioinformatics, 2005; 21(9):1935-42.

6. Kirazov LP, Venkov LG, Kirazov EP. Comparison of the Lowry and the Bradford protein assays as applied for protein estimation of membrane-containing fractions. Analytical biochemistry, 1993; 208(1):44-48.

7. Martina VR, Vojtech K. A comparison of Biuret, Lowry and Bradford methods for measuring the egg's proteins. Proceedings of the Mendel Net, 2015:394-398.

8. Kruger NJ. The Bradford method for protein quantitation, $p$ 15-21. The protein protocols handbook, 2nd ed. Humana Press, Totowa, NJ. 2002.

9. Shire SJ, Shahrokh Z, Liu JU. Challenges in the development of high protein concentration formulations. Journal of pharmaceutical sciences, 2004; 93(6):1390-402.

10. Zor T, Selinger Z. Linearization of the Bradford protein assay increases its sensitivity: theoretical and experimental studies. Analytical biochemistry, 1996; 236(2):302-308.

11. Ohnishi ST, Barr JK. A simplified method of quantitating protein using the biuret and phenol reagents. Analytical biochemistry, 1978; 86(1):193-200.
12. Lowry $\mathrm{OH}$, Rosebrough NJ, Farr AL, Randall RJ. Protein measurement with the Folin phenol reagent. Journal of biological chemistry, 1951; (193):265-75.

13. Oosta GM, Mathewson NS, Catravas GN. Optimization of FolinCiocalteu reagent concentration in an automated Lowry protein assay. Analytical biochemistry, 1978; 89(1):31-34.

14. Compton SJ, Jones CG. Mechanism of dye response and interference in the Bradford protein assay. Analytical biochemistry, 1985; 151(2):369-374.

15. Bradford MM. A rapid and sensitive method for the quantitation of microgram quantities of protein utilizing the principle of protein-dye binding. Analytical biochemistry, 1976; 2(1-2):248-254

16. Brown RE, Jarvis KL, Hyland KJ. Protein measurement using bicinchoninic acid: elimination of interfering substances. Analytical biochemistry, 1989; 180(1):136-139.

17. Smith PE, Krohn RI, Hermanson GT, Mallia AK, Gartner FH, Provenzano M, Fujimoto EK, Goeke NM, Olson BJ, Klenk DC. Measurement of protein using bicinchoninic acid. Analytical biochemistry, 1985; 150(1):76-85.

18. Noble JE, Bailey MJ. Quantitation of protein. In Methods in enzymology, 2009; 463:73-95.

19. Sapan CV, Lundblad RL, Price NC. Colorimetric protein assay techniques. Biotechnology and applied Biochemistry, 1999; (2):99-108.

20. Der-Balian GP, Gomez B, Masino RS, Parce JW. A fluorometric method for determining the degree of biotinylation of proteins. Journal of immunological methods, 1990; 126(2):281-285.

21. Iwata J, Nishikaze 0 . New micro-turbidimetric method for determination of protein in cerebrospinal fluid and urine. Clinical Chemistry, 1979; 25(7):1317-1319.

22. Nurahmanto D. Development and validation of UV spectrophotometric method for quantitative estimation of Promethazine $\mathrm{HCl}$ in phosphate buffer saline $\mathrm{pH}$ 7.4. International Current Pharmaceutical Journal, 2013; 2(8):141-142.

23. Sedlak J, Lindsay RH. Estimation of total, protein-bound, and nonprotein sulfhydryl groups in tissue with Ellman's reagent. Analytical biochemistry. 1968; 25:192-205.

24. Kruger NJ. The Bradford method for protein quantitation. In The protein protocols handbook, 2009; 17-24.

25. Beyer RE. A rapid biuret assay for protein of whole fatty tissues. Analytical biochemistry, 1983; 129(2):483-485.

26. Kocic G, Veljkovic A, Kocic H, Colic M, Mihajlovic D, Tomovic K, Stojanovic S, Smelcerovic A. Depurinized milk downregulates rat thymus MyD88/Akt/p38 function, NF-kB-mediated inflammation, caspase-1 activity but not the endonuclease pathway: In vitro/in vivo study. Scientific reports. 2017; 7:41971.

27. Oseas da Silva MA, Arruda MA. Mechanization of the Bradford reaction for the spectrophotometric determination of total proteins. Analytical biochemistry, 2006; 351(1):155-157.

28. Eaton SL, Roche SL, Hurtado ML, Oldknow KJ, Farquharson C, Gillingwater $\mathrm{TH}$, Wishart TM. Total protein analysis as a reliable loading control for quantitative fluorescent Western blotting. PloS one, 2013; 8(8):72457.

29. Welinder C, Ekblad L. Coomassie staining as loading control in Western blot analysis. Journal of proteome research, 2011; 10(3):1416-1419.

30. Verrills NM. Clinical proteomics: present and future prospects. Clinical Biochemist Reviews, 2006; 27(2):99. 